\title{
RAAS-mediated Redox effects in Chronic Kidney Disease
}

\author{
Ravi Nistala ${ }^{1,3,5}$, Yongzhong Wei ${ }^{1,5}$, James R Sowers ${ }^{1,2,4,5,6}$, and Adam Whaley- \\ Connell $1,3,5,6$
}

1 Department of Internal Medicine, University of Missouri-Columbia School of Medicine

2 Department of Medical Pharmacology and Physiology, University of Missouri-Columbia School of Medicine

3 Division of Nephrology, University of Missouri-Columbia School of Medicine

4 Division of Endocrinology, University of Missouri-Columbia School of Medicine

5 Diabetes and Cardiovascular Lab, University of Missouri-Columbia School of Medicine

6 Harry S Truman VA Medical Center, University of Missouri-Columbia School of Medicine

\begin{abstract}
The renin-angiotensin-aldosterone-system (RAAS) is central to the pathogenesis of hypertension, cardiovascular and kidney disease. Emerging evidence support various pathways through which a local renal RAAS can affect kidney function, hypertension, and cardiovascular disease. A prominent mechanism appears to be loss of redox homeostasis and formation of excessive free radicals. Free radicals such as reactive oxygen species (ROS) are necessary in normal physiologic processes including development of nephrons, erythropoeisis and tubular sodium transport. However, loss of redox homeostasis contributes to pro-inflammatory and pro-fibrotic pathways in the kidney that in turn lead to reduced vascular compliance, podocyte pathology and proteinuria. Both blockade of the RAAS and oxidative stress produces salutary effects on hypertension and glomerular filtration barrier injury. Thus, the focus of current research is on understanding the pathophysiology of chronic kidney disease in the context of an elevated RAAS and unbalanced redox mechanisms.
\end{abstract}

\section{Keywords}

Kidney; Renin; Angiotensin; Aldosterone; Redox

\section{INTRODUCTION}

The renin-angiotensin-aldosterone system (RAAS) is a complex endocrine, paracrine and autocrine system that modulates the function of the kidney. Recent work has focused on dissecting the role of local RAAS in the kidney and evidence is emerging for its role in diabetic, hypertensive chronic kidney disease (CKD). ${ }^{1,2}$ Apart from traditional role in the kidney, the discovery of local robust RAAS expression has been defined in kidney function and pathology.

Corresponding Author: Ravi Nistala, MD, MS, Fellow, Division of Nephrology, Department of Internal Medicine, University of MissouriColumbia School of Medicine, CE417, DC043.0, Five Hospital Dr, Columbia, MO 65212, Phone (573)882-7992, Fax (573)884-4820, E-mail: nistalar@health.missouri.edu.

Publisher's Disclaimer: This is a PDF file of an unedited manuscript that has been accepted for publication. As a service to our customers we are providing this early version of the manuscript. The manuscript will undergo copyediting, typesetting, and review of the resulting proof before it is published in its final citable form. Please note that during the production process errors may be discovered which could affect the content, and all legal disclaimers that apply to the journal pertain. 
As per the National Kidney Foundation (NKF)-Kidney Disease Outcomes Quality Initiative (KDOQI) consensus guidelines, CKD resulting from diabetes and hypertension remain the leading causes of renal morbidity and mortality. ${ }^{3}$ The basis for recognition of RAAS as the central player in the pathophysiology of CKD stems from several well-designed randomized clinical trials in Type 1 diabetes patients including the Collaborative Study Group (CSG) trial. ${ }^{4}$ In Type 2 diabetics, the Heart Outcomes Prevention Evaluation (HOPE), irbesartan on the development of diabetic nephropathy in patients with type 2 diabetes (IRMA2), MicroAlbuminuria Reduction With VALsartan (MARVAL), The Incipient to Overt: Angiotensin II Blocker, Telmisartan, Investigation on Type 2 Diabetic Nephropathy (INNOVATION), Irbesartan in Diabetic Nephropathy Trial (IDNT), Nephrologic Diabetes Complications Trial (BENEDICT), and Reduction of Endpoints in NIDDM with the Angiotensin II Antagonist Losartan (RENAAL) studies, have demonstrated clear benefits from RAAS blockade with angiotensin converting enzyme (ACE) inhibitors and angiotensin receptor blockers (ARBs) (Table I). ${ }^{5-14}$

The coexistence of RAAS activation and "oxidative stress" has generated extraordinary interest and is arguably the most important mechanism for diabetic CKD. Binding of angiotensin (Ang II) to the Ang type 1 receptor $\left(\mathrm{AT}_{1} \mathrm{R}\right)$, stimulates a series of signaling cascades that are divided into G-protein and non-G-protein related signaling. An example of a G-protein-dependent pathway is activation of phospholipase $\mathrm{C}$ (PLC) with the subsequent production of inositol 1,4,5-phosphate $\left(\mathrm{IP}_{3}\right)$ and diacylglycerol (DAG). $\mathrm{IP}_{3}$ then stimulates $\mathrm{Ca}^{2+}$-mediated activation of protein kinase $\mathrm{C}(\mathrm{PKC})$ that ultimately leads to activation of $\mathrm{NAD}(\mathrm{P}) \mathrm{H}$ oxidase enzyme complex and reactive oxygen species (ROS) generation. Non-G-protein-dependent pathways induced by Ang II include phosphorylation and activation of various tyrosine kinases. An example of this would be activation of epidermal growth factor receptor (EGFR) which then leads to activation of transcription factor c-Jun which could in turn induce ROS formation through $\mathrm{NAD}(\mathrm{P}) \mathrm{H}$ oxidase.

There is sufficient evidence to support the notion that Ang II promotes ROS formation via $\mathrm{NAD}(\mathrm{P}) \mathrm{H}$ oxidase activation by direct stimulatory effects (stimulation of the $\mathrm{AT}_{1} \mathrm{R}$ ); studies on inhibition of the RAAS have contributed to this evidence as well. ${ }^{15-21}$ Renal afferent arterioles when infused with Ang II at a slow pressor rate exhibit renal cortical $\mathrm{NAD}(\mathrm{P}) \mathrm{H}-$ stimulated superoxide $\left(\mathrm{O}_{2}{ }^{-}-\right)$generation and lipid peroxidation in addition to impaired acetycholine (Ach)-induced endothelium-dependent relaxation and enhanced contractile responses to Ang II. ${ }^{17}$ The arterioles have a profound downregulation of the mRNA for $\mathrm{AT}_{1} \mathrm{R}$ but an upregulation of the $\mathrm{p} 22^{\text {phox }}$ component of $\mathrm{NAD}(\mathrm{P}) \mathrm{H}$ oxidase. In addition, Ang II infusion in rats led to increased expression of $\mathrm{NAD}(\mathrm{P}) \mathrm{H}$ oxidase subunits, an effect abrogated with blockade of the $\mathrm{AT}_{1} \mathrm{R} .{ }^{15}$ Moreover, administration of $\mathrm{AT}_{2} \mathrm{R}$ inhibitor PD-123,319 resulted in worsening of Ang II mediated oxidative stress as $\mathrm{AT}_{2} \mathrm{R}$ is known to mediate the beneficial effects of Ang II stimulation.

Generation of excessive ROS leads to activation of transcription factors [nuclear factor-kappa B (NF-kB)], receptors [EGFR, prostaglandin PGE(2) (EP-1), receptor for advanced glycated products (RAGE)], cell signaling pathways [Janus-associated kinase-signal transducers and activators of transcription- $1 \alpha$ (JAK-STAT), mitogen activated protein kinase (MAPK)], cytokines [interleukin-6 (IL-6), tumor necrosis factor-alpha (TNF- $\alpha$ )], serine/threonine kinases (Akt, inhibitor of nuclear factor- $\kappa B$ (NF- $\kappa B\}$ kinase- $\beta($ IKK- $\beta$ ), ribosomal protein S6 kinase polymerase 1 (S6K1)] and other abnormal processes that disrupt the reduction-oxidation (redox) homeostasis of the cell and then the whole organ. ${ }^{2}$ Specific blockade of these deleterious pathways has been shown to decrease oxidative stress-mediated effects of RAAS. ${ }^{2}$ Ultimately, redox imbalances have been shown to lead to kidney injury and proteinuria. Hence, it is imperative that we understand the mechanisms through which the RAAS modulates 
kidney function and pathology to better able to prevent and control deterioration of kidney function.

In this review, we will discuss RAAS modulation of kidney function, abnormal RAAS activation in kidney disease, the role of redox status in mediation of RAAS effects and some therapeutic modalities that have been shown to have salutary effects on RAAS-mediated kidney disease.

\section{WHAT IS THE IMPORTANCE OF RAAS IN THE KIDNEY}

\section{A. Role in organ development}

Among varying roles of Ang II including sodium homeostasis and regulation of aldosterone synthesis, the involvement in renal organogenesis is compelling. ${ }^{21}$ Angiotensinogen (Aogen) mRNA was detected by days 30-35 of gestation in the mesonephros of human embryos, while $\mathrm{AT}_{1} \mathrm{R} \& \mathrm{AT}_{2} \mathrm{R}$ were detected by day $24 .{ }^{22}$ In the human metanephros, ACE was expressed in proximal tubule cells/cortical collecting ducts (PTC/CCD), Aogen in PTC at 8 wks, $\mathrm{AT}_{1} \mathrm{R}$ in glomeruli and PTC, and $\mathrm{AT}_{2} \mathrm{R}$ in the undifferentiated mesenchyme. ${ }^{21}$ The role of Ang II in the development of kidneys is supported by evidence from deletion of the Aogen gene in mice (Agt -l-). The consequent defective kidney organogenesis is lethal within 10 days of birth. 23,24 Aogen is mainly expressed in the kidney tubules of mice by embryonic day 17 and its expression declines shortly after birth. It is known the RAAS is up-regulated during renal development and in the perinatal period; the $\mathrm{AT}_{1} \mathrm{R}$ is expressed at high levels post partum, while $\mathrm{AT}_{2} \mathrm{R}$ expression is higher in the kidney pre-partum. ${ }^{25}$ Evidence now suggests that Ang II stimulates growth of tubular cells in vitro and induces synthesis of collagen IV mediated through the $\mathrm{AT}_{1} \mathrm{R} .{ }^{26}$ Complete knockout of $\mathrm{AT}_{1} \mathrm{R}$ results in lack of development of renal pelvis and ureteral peristaltic movement; in fact, the phenotype is mimicked by wild type mice with one ureter ligated (obstructive uropathy). ${ }^{27}$ Similarly, mice with targeted mutations in the ACE, $\mathrm{AT}_{1} \mathrm{R}$, and in both renin genes, have nearly identical phenotypes characterized by poor survival to weaning, low blood pressure, and abnormal kidney structure. Their kidneys develop thickened with hypercellular arterial walls, interstitial fibrosis, inflammation, papillary atrophy, and tubular dilation. Interestingly, gene targeting of angiotensinogen/ACE produces a more severe phenotype when compared to AT receptor targeting. The reason could very well be the effects on non-AT receptor mediated pathways, such as aldosterone-mediated mineralocorticoid receptor (MR) activation or it could even be $\mathrm{AT}_{2}$ receptor-mediated signaling. ${ }^{28}$ As a corollary, consumption of ACE inhibition during pregnancy has been shown to result in kidney malformation mainly through defective angiogenesis/tubulogenesis. Thus, Ang II and the RAAS contribute to normal growth and development of the nephron through an interplay of $\mathrm{AT}_{1} \mathrm{R}$ and $\mathrm{AT}_{2} \mathrm{R}$ mediated effects and has additional roles in cell cycle progression. ${ }^{29}$

\section{B. Fluid and salt homeostasis}

The classic RAAS is endocrine in function with renin secreted from juxtaglomerular apparatus (JGA) in response to low blood flows, angiotensinogen from liver and ACE from lung. Ang II is cleaved from Ang I by ACE in the blood and causes peripheral vasoconstriction and tubular reabsorption of sodium. It also increases tubular reabsorption of urinary protein (albumin). Aldosterone is secreted by aderenal glands in response to Ang II and augments Ang II mediated attempts to conserve volume by retaining sodium in the distal tubules. Ang II also has aldosterone independent effects on sodium retention via $\mathrm{ENaC}$ in distal tubules. ${ }^{30}$ However, evidence emerging from several labs has demonstrated all components of RAAS pathway in several extra renal sites including brain, liver, lungs, heart, pancreas, kidneys, vasculature and skeletal muscle. The beneficial effects of RAAS actually become harmful when this system is 
turned on excessively due to dysregulation of redox homeostasis likely due to loss of normal feedback suppression mechanisms.

\section{RAAS IN THE KIDNEY}

With the increase of newly identified components and functions, knowledge about the RAAS has significantly expanded in the last two decades. Besides "classical" RAAS, recently, compelling evidence indicates that there are also local and intracellular RAAS systems in various organs/tissues/cells. Indeed, the local RAAS has gained a great deal of attention in the pathophysiology of organ/tissue injury, particularly in the kidneys (Figure 1). It has been demonstrated that kidneys produce/express all of the RAAS components including renin, Aogen, Ang II, (pro)renin receptor, ATR's and MR. ${ }^{25,28,31-34}$ Local RAAS may be particularly important in kidney injury and dysfunction via induction of inflammation, cell growth, mitogenesis, apoptosis, migration, and differentiation, through activation of multiple intracellular signaling pathways (Figure 1). ${ }^{21}$ Although the role of circulating RAAS cannot be minimized, renal RAAS activation has been demonstrated through various paradigms to contribute to the development and progression of hypertension. 1,35-41 Importantly, renal $\mathrm{AT}_{1} \mathrm{R}$ activation has been shown to influence systemic hypertension compared to systemic contributions of the $\mathrm{AT}_{1} \mathrm{R}$. Investigators utilized a kidney cross-transplantation technique to compare four groups of mice: wild type group containing transplanted kidneys from wild type donors expressing $\mathrm{AT}_{1 \mathrm{~A}}$ receptor ( $\mathrm{AT}_{1 \mathrm{~A}}$ in mouse is most homologous to $\mathrm{AT}_{1}$ in humans) in the kidney transplant and in all systemic tissues, systemic $\mathrm{AT}_{1 \mathrm{~A}} \mathrm{R}$ KO group transplanted with kidney expressing $\mathrm{AT}_{1 \mathrm{~A}}$, kidney $\mathrm{AT}_{1 \mathrm{~A}} \mathrm{R} \mathrm{KO}$ group expressing $\mathrm{AT}_{1 \mathrm{~A}}$ in all tissues except for kidney and total $\mathrm{KO}$ group with no expression of $\mathrm{AT}_{1 \mathrm{~A}} \cdot{ }^{35} \mathrm{Blood}$ pressure measurements between he groups suggested that systemic and kidney $\mathrm{AT}_{1 \mathrm{~A}}$ made equal contributions to baseline blood pressure. However, when mice were stimulated with Ang II, the systemic KO group had similar pressures to wild type group suggesting that hypertension was mediated primarily through kidney $\mathrm{AT}_{1 \mathrm{~A}} \mathrm{R}$ and not through systemic $\mathrm{AT}_{1 \mathrm{~A}} \mathrm{R}$. Additional deleterious effects of kidney $\mathrm{AT}_{1 \mathrm{~A}}$ activation include decreased sodium excretion, weight gain, cardiac hypertrophy, atrial natriuretic peptide and brain natriuretic peptide stimulation, further demonstrating the important role of kidney $\mathrm{AT}_{1 \mathrm{~A}}$ in cardiovascular pathology.

\section{Renin, prorenin and (pro)renin receptor}

The JGA in the kidney are known to contribute to both circulating and intra-renal renin levels. ACE inhibition increases the staining for renin by recruitment of additional cells of the afferent arterioles alongside the JGA. ${ }^{42}$ In addition, evidence for the expression of renin in the afferent artery, glomerular cells, proximal and distal tubular cells, possibly connecting tubule cells, exists. ${ }^{31}$ It is well established that the role of renin is to cleave Aogen into Ang I. Recent evidence suggests that renin also exerts direct effects via binding to (pro)renin receptor (P)RR, such as activation of extracellular signal-regulated kinases (ERK) $1 / 2$, stimulation of transforming growth factor $-\beta$ (TGF- $\beta$ ) and collagen I and p38MAPK. ${ }^{43,44}$ This receptor has been associated with circulating renin/prorenin uptake by some tissues where it may contribute to the local synthesis of Ang peptides. ${ }^{34,43,45,46}$ It has been reported that glomerular mesangial cells and subendothelial space of the renal vasculature specifically partition the $(\mathrm{P})$ RR. ${ }^{43}$ The presence of the receptor in renal tubules may contribute to tubular generation of Ang II through enhanced conversion of locally produced Aogen to Ang I. ${ }^{47}$ In addition, a recent study indicates that prorenin plays a pivotal role in the development of diabetic nephropathy via binding to an intrinsic prorenin-binding receptor. ${ }^{48,49}$

\section{Aogen}

The liver is the major organ producing Aogen. The kidneys also express Aogen, particularly in the podocytes, proximal tubules, distal convoluted tubules and renal endosomes. $31,33,50-$ 
53 It is also expressed weakly in the glomerular endothelial cells. ${ }^{1}$ In addition to Aogen, the proximal tubule cells produce renin and express abundant amounts of ACE on the proximal tubule brush border. The proximal tubule cells secrete Aogen into the tubular lumen, which in turn leads to intraluminal Ang II formation with the potential to activate distal sodium retention. 1,36 These findings indicate that Aogen can be converted into Ang II locally in the kidneys. Through elegant experiments Kobori et al showed that Aogen is not filtered across the glomerulus further demonstrating that Aogen must be locally generated from the tubules. Transgenic mice overexpressing Aogen under control of kidney androgen promoter, exhibit high expression in the proximal tubule cells and high levels of the protein in the urine once again demonstrating the existence of tubular secretion of Aogen. 36

\section{ACE}

ACE was believed to originate in the pulmonary epithelium, however ACE is expressed abundantly on the brush-border membrane of PTC's. In fact, it may be expressed all along the length of a nephron. ${ }^{54}$ In contrast to rats, ACE is only minimally expressed in human vascular endothelial cells (at $10 \%$ of rat levels), which raises an important point that in humans, circulating Ang II contributes less to kidney RAAS than local RAAS itself. 55

\section{Ang II}

Intrarenal Ang II is distributed widely in the cortex and medulla. ${ }^{56}$ Within the cortex, there is distribution of Ang II in the interstitial fluid, tubular fluid, and intracellular compartments. $32,57,58$ Studies suggest that Ang II plays an important role in proximal, distal and collecting duct sodium reabsorption. ${ }^{30,59}$ Intracellular Ang II has also been identified in proximal tubule cells. For example, increased Ang II was detected in renal endosomes and intramicrovillar clefts in proximal tubule cells. Ang II bound to receptors is internalized via $\mathrm{AT}_{1} \mathrm{R}$-mediated endocytosis. ${ }^{60-63}$ Internalized Ang II could be recycled and secreted to exert further actions by binding to Ang II receptors on the cell membranes. The intracellular Ang II may also bind to cytosolic receptors to stimulate the inositol 1,4,5-triphosphate pathway. ${ }^{64}$ The intracellular Ang II may migrate to the nucleus and bind to $\mathrm{AT}_{1}$ subtype or distinguished nuclear receptors, which in turn exert genomic actions to regulate Aogen or renin mRNA expression in proximal tubule cells. 65,66

\section{MR and ENaC}

Traditionally, the actions of aldosterone on the kidney have been thought to be active only in the collecting ducts. However, MR on the podocytes have been shown to mediate aldosterone mediated glomerular sclerosis. ${ }^{67}$ Furthermore, amiloride sensitive ENaC are expressed in renal distal convoluted tubules (DCT), connecting tubules (CNT), cortical collecting ducts (CCD), and outer medullary collecting ducts (OMCD), but not in the inner medullary collecting ducts (IMCD), consistent with tighter regulation of sodium transport in the cortex and outer medulla. 68

\section{$A T_{1} R$ and $A T_{2} R$}

$\mathrm{AT}_{1} \mathrm{R}$ is expressed most prominently in the interlobular arteries and tubulointerstitial fibrous regions surrounding interlobular arteries and glomeruli, followed in decreasing order by glomeruli and cortical tubules. 69,70 Among the tubular cells, the proximal tubule brush-border and basolateral membranes, distal tubules, cortical and medullary collecting ducts exhibited specific immunoreactivity. ${ }^{70-72}$ Glomerular staining for $\mathrm{AT}_{1} \mathrm{R}$ was observed in mesangial cells and podocytes. Macula densa cells stained positively as well. ${ }^{73} \mathrm{AT}_{2} \mathrm{R}$ expression has been confined to the interlobular arteries. ${ }^{71}$ The regulation of $\mathrm{AT}_{1} \mathrm{R}$ is highly variable depending on the volume status of the animal, but in general glomerular $\mathrm{AT}_{1} \mathrm{R}$ are decreased and tubular, increased in response to excess Ang II. ${ }^{1}$ Upregulation of $\mathrm{AT}_{1} \mathrm{R}$ in multiple tissues 
may explain hypertension in transgenic Ren2 rats [(mRen2)27] even though plasma Ang II levels are not elevated. ${ }^{1}$

\section{EXCESS RAAS AND CHRONIC KIDNEY DISEASE}

\section{A. Increased intraglomerular pressure, decreased GFR, increased tubular sodium transport}

Human and animal studies have shown that Ang II infusions lead to increased constriction of both afferent and efferent arterioles and lead to increases in intraglomerular pressures and decrease in GFR. ${ }^{1}$ However, increased tubular transport of sodium may be a more significant role for Ang II in the kidney. Apical $\mathrm{Na}^{+} / \mathrm{H}^{+}$exchange, basolateral $\mathrm{Na}^{+}-\mathrm{HCO}^{-}$cotransport, and basolateral $\mathrm{Na}^{+} / \mathrm{K}^{+}$-ATPase via insertion of $\mathrm{H}^{+}$-ATPase into the apical membrane, may be some of the mechanisms leading to increased solute retention. ${ }^{1}$ Sustained increases in volume leads to increases in BP and the consequent long-term effects of RAAS activation. As a corollary, one would imagine that decrease in kidney tissue ACE would lead to decrease in BP. However, kidney specific ACE knockout mice did not manifest low BP and were able to maintain fluid and solute homeostasis via liver ACE alone. This shows that although kidney ACE is important, other compensatory mechanisms may come into play at the whole animal level.

\section{B. Increased oxidative stress, altered tubuloglomerular feedback (TGF)}

There is sufficient and convincing evidence to support Ang II as a key contributor to progression of kidney disease by stimulating growth, hypertrophy, oxidative stress, inflammation and fibrosis within the kidney (Figure 1). Many of the same downstream to $\mathrm{AT}_{1} \mathrm{R}$ pathways that are invoked in the vasculature, hold true in the kidney as well (e.g. DAG/ $\mathrm{Ca}^{2+} / \mathrm{PKC}$ signaling, g-protein/Rac1 signaling, MAPK/TGF- $\beta 1$ signaling, insulin growth factor-1 (IGF-1)/insulin receptor substrate-1 (IRS-1) signaling, and NAD(P)H oxidase/ROS signaling).

As described above, all the RAAS components are expressed and functional in the kidney. RAAS activation leads to activation of ROS generating enzyme systems which include metabolic oxygenases such as $\mathrm{NAD}(\mathrm{P}) \mathrm{H}$ oxidase. ${ }^{2,20,74}$ This enzyme complex is believed to be the major source of abnormal cellular signaling, although in terms of quantity the mitochondrial respiratory chain system may generate the most superoxide anion. ${ }^{2,74}$ All of the components necessary to for this enzyme complex to function in the kidney are expressed in the various kidney cell types. ${ }^{2}$ Nox 4 is expressed at high levels in kidney and other Nox's, including Nox1, Nox2, and Nox regulatory subunits, are expressed at lower but quantitatively significant levels making Nox enzymes attractive candidates for the origin of renal ROS including the relatively high levels of $\mathrm{H}_{2} \mathrm{O}_{2}$ seen in urine. ${ }^{75-82}$ There appears to be no consensus for the cortico-medullary differences between the different subunits as the literature has data from different animals undergoing different treatments. Indeed, a few studies have demonstrated none or very little expression of the regulatory subunits in the medulla. In contrast, one group reported that in spontaneously hypertensive rats (SHR) the expression of Nox 1 , Nox 2 and p67phox is higher in the renal medulla when compared to the cortex and the expression of Nox 4 and p $22^{\text {phox }}$ is higher in the cortex than the medulla. ${ }^{83}$ Furthermore, the expression of $\mathrm{p} 47^{\text {phox }}$ is about the same in the cortex versus the medulla. The mesangial cells are unique in that they express Nox 1 , Nox $4, \mathrm{p} 22^{\text {phox }}, \mathrm{p} 47^{\text {phox }}$ and $\mathrm{p} 67^{\text {phox }}$ but not Nox $2 .{ }^{77}$, $78,84,85$ This may be biologically important as there is data supporting the fact that mesangial cells may be similar to vascular smooth muscle cells (VSMC's), which also lack Nox2 (expressed at very low levels). In mesangial cells, NO inhibits the expression of Nox1, suggesting a cross-talk between $\mathrm{NO}$ and $\mathrm{O}_{2}{ }^{--}$generating systems. ${ }^{79}$ p22 $2{ }^{\text {phox }}$, p4 $47^{\text {phox }}$ and p67phox are all expressed in the PCT, DCT, CCD and the macula densa cells. ${ }^{86-90}$ Nox2 expression has been shown in the PCT and CCD, Nox4 in the PCT and DCT, while Nox1 
expression is confined to the PCT, once again demonstrating differential regulation of redox control within the cortex. In situ hybridization experiments initially localized Nox4 mRNA expression to renal cortex, while the medulla showed much lower expression. ${ }^{79,81}$ However, immunohistochemical studies demonstrate Nox4 expression in distal portions of the human nephron, specifically, Nox4 mRNA has been demonstrated in medullary collecting ducts. 79 , 81 Moreover, as mentioned above the data for Nox 4 was obtained from different animal groups. Nox4 isoform of NAD(P)H oxidase is unique in that, it can also use $\mathrm{NADH}$ as the substrate for generating $\mathrm{O}_{2}{ }^{\bullet-91}$ This may be relevant to the kidneys, as the cortex and outer medulla preferentially use NADH as substrate and express Nox4 at high levels in these regions. ${ }^{92}$

Most importantly, Nox4 is integral in the development of the renal complications of insulin resistance and hypertension. ${ }^{20,67}$ Increased expression of Nox 4 and p22 ${ }^{\text {phox }}$ and accumulation of 8-hydroxy-deoxyguanosine (8-OHdG), marker for ROS-induced DNA damage, in the kidney of streptozotocin-induced diabetic rats was reversed after treatment with insulin for 2 weeks. ${ }^{93}$ Another group working with the same animal model showed that, infusing antisense oligonucleotides for 2 weeks targeting Nox 4 mRNA was effective in reducing ROS both in cortical and glomerular homogenates, organelle hypertrophy and fibronectin expression, which are characteristic markers of diabetic kidney disease. One putative pathway proposed to increase Nox 4 expression has been the Rho/Rho-kinase pathway and this was inhibited by administration of fasudil (Rho-kinase inhibitor) and statins. ${ }^{94}$ Ang-(1-7) peptide [Ang-(1-7)] attenuated Nox 4 expression, decreased NAD $(\mathrm{P}) \mathrm{H}$ oxidase activity and improved proteinuria in streptozotocin treated SHR (diabetic SHR). ${ }^{95}$ These data suggest a signaling role for Nox4derived ROS in the development of diabetic kidney disease. ${ }^{96}$ The Ren 2 transgenic rat is a unique model for investigating the influence of kidney Ang II and the RAAS on redox control of the kidney. ${ }^{2,20,97}$ The Ren2 rat over-expresses the mouse renin transgene and demonstrates elevated tissue Ang II including a local renal tissue RAAS. Elevated tissue RAAS has been shown to increase oxidative stress in these animals contributing to insulin resistance, hypertension, and proteinuria. We have shown that Ang II increased Nox4 expression in the kidney/podocytes and that this was associated with proteinuria and hypertension in these animals. ${ }^{20,97}$ Furthermore, we have shown increased expression of NAD(P)H oxidase subunits in the glomeruli including Nox2, p47phox p67phox, Rac1. ${ }^{20,97}$ There was increased $\mathrm{NAD}(\mathrm{P}) \mathrm{H}$ oxidase activity and increased 3-nitrotyrosine (3-NT) staining demonstrating increased ROS generation via increased enzyme activity. With the electron microscope, we have observed increased podocyte effacement, basement membrane thickening, slit pore diaphragm widening and decrease in slit pore numbers in Ren 2 transgenic rat and these defects were ameliorated with ARBs, superoxide dismutase mimetic (tempol). ${ }^{20,97}$ We have also observed that blockade of both RAAS and ROS ameliorate proteinuria thereby implicating a RAAS-mediated redox imbalance pathway. ${ }^{20}$ Blockade of RAAS/ROS also abrogated changes of nephrosclerosis at the structural level. Importantly, these experiments revealed that modulation of the RAAS, independent of blood pressure, had salutary effects on kidney function.

Several groups have demonstrated that ROS can decrease both NO generation and function in the kidney. ${ }^{19}$ ROS has been shown to convert NO to a ROS species called peroxintrite (ONOO-). NO decreases TGF thereby exquisitely controlling retention of sodium till the body extracellular fluid is replete. Peroxinitrite acting in the JGA can increase the tubuloglomerular feedback leading to retention of sodium by the tubules even though the body is replete with sodium, resulting in hypertension and volume overload. Importantly, blockade of $\mathrm{AT}_{1} \mathrm{R}$ ameliorated ROS induced increases in TGF, linking RAAS activation to ROS-mediated redox alterations. ${ }^{19}$ 


\section{Clinical studies}

RAAS-mediated mechanisms for ROS production in the kidney are currently a subject of intense interest in the nephrology community. This is mostly due to K-DOQI identifying this area as a focus of research and the existence of identifiable human disease from overexpression/mutations/polymorphisms in the renin, Aogen, $\mathrm{ACE}, \mathrm{AT}_{1} \mathrm{R}$, aldosterone, and MR genes. ${ }^{2}$ An example of this principle exists in a Dutch cohort with insulin-dependent diabetes mellitus (IDDM)-induced incipient diabetic kidney disease. ${ }^{98}$ Within this population, the Tallele of the Aogen-M235T polymorphism is associated with increases in proteinuria and the $\mathrm{CC}$-genotype of the $\mathrm{AT}_{1}$ - $\mathrm{A} 1166 \mathrm{C}$ polymorphism is associated with hypertension. In addition, mutations in other components of RAAS pathways are also associated with hypertension. However, monogenetic forms of HTN constitute only 5\% of total disease burden and the search for better markers of disease e.g. defining phenotypes by clustering of factors such as hyperinsulinemia, cholesterol and lipids, waist circumference and hyperglycemia is gaining momentum. Importantly, the debate about identifying renal disease by markers other than proteinuria has intensified urging investigators to look for alternate and more robust markers of CKD. 8-OHdG is one such marker that can be measured in the urinary samples of patients and indicates oxidative stress and damage to glomerular filtration barrier injury. Recently, better assays (ELISA) have been developed to measure Aogen in the urine and plasma, these remain to be tested in humans and on a larger scale. ${ }^{99}$

\section{THERAPY FOR EXCESS RAAS-MEDIATED KIDNEY INJURY}

\section{a. ARBs/ACEi's (Valsartan, Irbesartan, losartan,)}

Several well designed clinical trials have guided us in therapy of elevated RAAS in hypertension and diabetic kidney disease. These include the clinical trials listed in Table 1. The mechanism for improvement in glomerular filtration barrier injury and/or proteinuria has been proposed to be BP dependent or BP independent. The BP independent mechanisms for benefit from RAAS blockade include mitigation of pro-inflammatory and pro-fibrotic pathways (Figure 1). We and others have used transgenic rat models and genetic models of hypertension and glomerular filtration barrier injury to demonstrate benefit from RAAS blockade with ARBs/ACE inhibitors including valsartan, irbesartan and losartan. We have demonstrated that while BP was reduced with these drugs, the tissue benefits were beyond that anticipated by BP control alone including amelioration of proteinuria, slit diaphragm widening, podocyte effacement, decrease in number of slit pores and basement membrane widening. We have also shown decrease in perivascular fibrosis with Verhoeff-van Gieson (VVG) stain and trichrome; decrease in oxidative stress with 3-NT in glomeruli, 8-OHdG in urine, $\mathrm{NAD}(\mathrm{P}) \mathrm{H}$ oxidase activity, enzyme subunits by western blots and immunohistochemistry; translocation of Rac1 to plasma membrane, decreased transcription of subunits. Others have demonstrated that ARB's decrease glomerulosclerosis in Streptozotocin-diabetic rats, SHR and Zucker obese rats. ${ }^{2}$ Telmisartan an ARB with unique perxisome proliferator activator receptor- gamma (PPAR- $\gamma$ ) agonist activity may have effects on insulin sensitivity in addition to its blood pressure lowering effects sans the nagging side effects of full PPAR- $\gamma$ agonists e.g. fluid retention (thiazolidinediones).

\section{b. Control of oxidative stress-antioxidants (tempol, apocyanin, DPI)}

That there are BP independent effects of RAAS has been made prominent initially through ROS blockade. Although there may be some debate about whether it is $\mathrm{NAD}(\mathrm{P}) \mathrm{H}$ oxidase or other oxygenases, it is clear that reduction in $\mathrm{NAD}(\mathrm{P}) \mathrm{H}$ oxidase activity and hence ROS, can ameliorate glomerular filtration barrier injury on its own. However, the full spectrum of benefit that stems from ARBs/ACE inhibitors is not evident. Other novel ways to block NAD(P)H oxidase activity including gp91 ds-tat, siRNA, monoclonal antibodies are being tried and hold 
great promise for not only hypertension but also for other disease processes with elevated oxidative stress.

\section{c. Statins (rosuvastatin)}

These drugs have great potential in the blockade of RAAS-mediated kidney injury through reduction of oxidative stress via inhibition of Rac1 translocation to the membrane, possible reduction in inflammation via NF- $\kappa$ B, IL-6, C-reactive peptide (hSCRP) and TNF- $\alpha .97,100$ Again, the benefits are BP-independent, through decrease in inflammation and fibrosis, increase in plaque stability and, finally, decrease in glomerular filtration barrier injury.

\section{d. MR antagonists (spironolactone)}

Spironolactone was originally used as an antihypertensive due to its aldosterone blocking effects in the distal tubules, however it is well known now over the past 5-7 years that aldosterone has roles similar to Ang II in tissue inflammation and fibrosis. RALES and EPHESUS have shown that addition of spironolactone to New York Heart Association (NYHA) 2/3 and post myocardial infarction (MI) patients, improves morbidity and mortality significantly. ${ }^{2}$ Our lab has shown that this drug can ameliorate oxidative stress, improve insulin sensitivity/resistance in the skeletal muscle and kidney (manuscripts submitted). Interestingly, the benefits were evident without major reductions in BP. MR receptors have been demonstrated in the kidney by Shibata et al (and unpublished work) and eplerenone was used to demonstrate improvement in glomerulosclerosis in Sprague Dawley rats undergoing aldosterone infusions. ${ }^{67}$

\section{e. Renin bocker (Aliskiren)}

Direct renin inhibition has been shown through recent clinical trials to have added benefits to baseline ARBs/ACE inhibitors further demonstrating the usefulness of RAAS blockade (AVOID trial). ${ }^{102}$ Aliskiren, the first orally available drug in its class, blocks renin and prorenin by binding to their active site. It inactivates prorenin by keeping it in the open configuration. In addition, it has also been postulated to bind to (P)RR, decrease the gene expression of (P)RR and alter the 3D configuration of renin. ${ }^{101}$ However, it may not alter the binding of renin to $(\mathrm{P}) \mathrm{RR} .{ }^{100} \mathrm{We}$ and others have shown that independent of BP reduction, direct renin inhibition leads to reduction in 3- NT staining, decrease in perivascular fibrosis, albuminuria, improved insulin sensitivity in ex vivo samples (unpublished observations). ${ }^{101}$

\section{f. $\beta$-blockers (Nebivolol?)}

The search for drugs that can be combined for maximum benefit sometimes leads to drugs that have dual effects. One such drug is the $\beta$-blocker Nebivolol that may possess vasodilatory properties in addition to traditional selective $\beta$-blockade. Nebivolol has been proposed to achieve these effects via recruitment of endothelial nitric oxide synthase (eNOS) and decrease in superoxide activity. ${ }^{103}$ This has sparked off interest in the use of this drug in preventing complications from CVD and CKD.

\section{FUTURE PERSPECTIVES}

The role of local RAAS in normal function of the kidney and pathogenesis of chronic kidney disease is complex. The RAAS interacts with a myriad of cytosolic factors, cellular and extracellular signaling pathways for seamless control of cellular mechanisms and the kidney as a whole. Dysregulation of these intracellular processes contribute to an imbalance in redox homeostasis and oxidative stress. Our understanding of renal NAD $(\mathrm{P}) \mathrm{H}$ oxidase is expanding in many of the RAAS-mediated effects, which lead to increased ROS formation, oxidative stress, redox imbalance and hypertension. 
Small animal and genetic investigations have expanded our understanding of hypertension and chronic kidney disease. The incorporation of various cell lines have further contributed towards understanding basic signaling pathways. However, our understanding of signaling pathways among the numerous cells within the kidney and how they contribute to renal function is variable at best. Modification of the RAAS mediated oxidative stress in the kidney has provided our best clinical understanding of renal redox handling as it relates to kidney function and hypertension.

Identifying chronic kidney disease early and modifying the risk factors has become a prerogative of many nations that are faced with the epidemic of this disease. Although proteinuria has been used as marker in many clinical trials, its correlation with hard renal outcomes is variable at best. Understanding the interplay of RAAS with redox mechanisms in chronic kidney disease may provide new markers to test for reliably identifying CKD early in its course. Further development of podocyte biology will likely facilitate this process.

\section{Acknowledgements}

Dr Adam Whaley-Connell is supported through the VA, Missouri Kidney Program and National Kidney Foundation and Dr James R Sowers is supported through the NIH and VA.

\section{References}

1. Kobori H, Nangaku M, Navar LG, Nishiyama A. The intrarenal renin-angiotensin system: from physiology to the pathobiology of hypertension and kidney disease. Pharmacol Rev 2007;59:251-87. [PubMed: 17878513]

2. Nistala R, Whaley-Connell A, Sowers JR. Antioxid Redox Signal 2008;10:2047-89. [PubMed: 18821850]

3. National Kidney Foundation. K/DOQI clinical practice guidelines for chronic kidney disease: evaluation, classification, and stratification. Am J Kidney Dis 2002;39:S1-266. [PubMed: 11904577]

4. Lewis EJ, Hunsicker LG, Bain RP, Rohde RD. The effect of angiotensin-converting-enzyme inhibition on diabetic nephropathy. The Collaborative Study Group. N Engl J Med 1993;329:1456-1462. [PubMed: 8413456]

5. Mann JF, Gerstein HC, Pogue J, Bosch J, Yusuf S. Renal insufficiency as a predictor of cardiovascular outcomes and the impact of ramipril: The HOPE randomized trial. Ann Intern Med 2001;134:629_ 636. [PubMed: 11304102]

6. Mann JF, Gerstein HC, Yi QL. Development of renal disease in people at high cardiovascular risk: results of the HOPE randomized study. J Am Soc Nephrol 2003;14:641-7. [PubMed: 12595499]

7. Parving HH, Lehnert H, Brochner-Mortensen J, Gomis R, Andersen S, Arner P. The effect of irbesartan on the development of diabetic nephropathy in patients with type 2 diabetes. N Engl J Med 2001;345:870-878. [PubMed: 11565519]

8. Ahmad J, Siddiqui MA, Ahmad H. Effective postponement of diabetic nephropathy with enalapril in normotensive type 2 diabetic patients with microalbuminuria. Diabetes Care 1997;20:1576-1581. [PubMed: 9314638]

9. Capes SE, Gerstein HC, Negassa A, Yusuf S. Enalapril prevents clinical proteinuria in diabetic patients with low ejection fraction. Diabetes Care 2000;23:377-380. [PubMed: 10868869]

10. Viberti G, Wheeldon NM, et al. MicroAlbuminuria Reduction With VALsartan (MARVAL) Study Investigators. Microalbuminuria reduction with valsartan in patients with type 2 diabetes mellitus: a blood pressure-independent effect. Circulation 2002;106:672-678. [PubMed: 12163426]

11. Makino H, Haneda M, Babazono T. INNOVATION Study Group. Prevention of transition from incipient to overt nephropathy with telmisartan in patients with type 2 diabetes. Diabetes Care 2007;30:1577-8. [PubMed: 17389334]

12. Ruggenenti P, Fassi A, Ilieva A, et al. Nephrologic Diabetes Complications Trial (BENEDICT) Investigators. Preventing microalbuminuria in type 2 diabetes. N Engl J Med 2004;351(19):19411951. [PubMed: 15516697] 
13. Lewis EJ, Hunsicker LG, Clarke WR, et al. Renoprotective effect of the angiotensin-receptor antagonist irbesartan in patients with nephropathy due to type 2 diabetes. N Engl J Med 2001;345:851-860. [PubMed: 11565517]

14. Brenner BM, Cooper ME, de Zeeuw D, et al. Effects of losartan on renal and cardiovascular outcomes in patients with type 2 diabetes and nephropathy. N Engl J Med 2001;345:861-869. [PubMed: 11565518]

15. Chabrashvili T, Kitiyakara C, Blau J. Effects of ANG II type 1 and 2 receptors on oxidative stress, renal NADPH oxidase, and SOD expression. Am J Physiol Regul Integr Comp Physiol 2003 Jul;285 (1):R117-24. [PubMed: 12609817]

16. Jaimes EA, Galceran JM, Raij L. Angiotensin II induces superoxide anion production by mesangial cells. Kidney Int 1998 Sep;54(3):775-84. [PubMed: 9734602]

17. Wang D, Chen Y, Chabrashvili T. Role of oxidative stress in endothelial dysfunction and enhanced responses to angiotensin II of afferent arterioles from rabbits infused with angiotensin II. J Am Soc Nephrol 2003 Nov;14(11):2783-9. [PubMed: 14569088]

18. Welch WJ, Mendonca M, Aslam S, Wilcox CS. Roles of oxidative stress and AT1 receptors in renal hemodynamics and oxygenation in the postclipped 2K,1C kidney. Hypertension $2003 \mathrm{Mar}$;41(3 Pt 2):692-6. [PubMed: 12623981]

19. Welch WJ, Wilcox CS. AT1 receptor antagonist combats oxidative stress and restores nitric oxide signaling in the SHR. Kidney Int 2001 Apr;59(4):1257-6. [PubMed: 11260386]

20. Whaley-Connell AT, Chowdhury NA, Hayden MR, et al. Oxidative stress and glomerular filtration barrier injury: role of the renin-angiotensin system in the Ren2 transgenic rat. Am J Physiol Renal Physiol 2006;291:F1308-14. [PubMed: 16788142]

21. Paul M, Poyan Mehr A, Kreutz R. Physiology of local renin-angiotensin systems. Physiol Rev 2006;86:747-803. [PubMed: 16816138]

22. Schütz S, Le Moullec JM, Corvol P, Gasc JM. Early expression of all the components of the reninangiotensin-system in human development. Am J Pathol 1996;149:2067-79. [PubMed: 8952539]

23. Ding Y, Stec DE, Sigmund CD. Genetic evidence that lethality in angiotensinogen-deficient mice is due to loss of systemic but not renal angiotensinogen. J Biol Chem 2001;276:7431-6. [PubMed: 11096065]

24. Smithies O, Kim HS. Targeted gene duplication and disruption for analyzing quantitative genetic traits in mice. Proc Natl Acad Sci U S A 1994;91:3612-5. [PubMed: 8170956]

25. Wolf G. Angiotensin II and tubular development. Nephrol Dial Transplant 2002;17 (Suppl 9):48-51. [PubMed: 12386287]

26. Wolf G, Kalluri R, Ziyadeh FN, Neilson EG, Stahl RA. Angiotensin II induces alpha3(IV) collagen expression in cultured murine proximal tubular cells. Proc Assoc Am Physicians 1999;111:357-64. [PubMed: 10417744]

27. Miyazaki Y, Tsuchida S, Fogo A, Ichikawa I. The renal lesions that develop in neonatal mice during angiotensin inhibition mimic obstructive nephropathy. Kidney Int 1999;55:1683-95. [PubMed: 10231430]

28. Wolf G. "The road not taken": role of angiotensin II type 2 receptor in pathophysiology. Nephrol Dial Transplant 2002;17:195-8. [PubMed: 11812862]

29. Wolf G, Wenzel UO. Angiotensin II and cell cycle regulation. Hypertension 2004;43:693-8. [PubMed: 14967829]

30. Peti-Peterdi J, Warnock DG, Bell PD, et al. Angiotensin II directly stimulates ENaC activity in the cortical collecting duct via AT(1) receptors. J Am Soc Nephrol 2002;13:1131-5. [PubMed: 11960999]

31. Liebau MC, Lang D, Böhm J, et al. Functional expression of the renin-angiotensin system in human podocytes. Am J Physiol Renal Physiol 2006;290:F710-9. [PubMed: 16189286]

32. Siragy HM, Howell NL, Ragsdale NV, Carey RM. Renal interstitial fluid angiotensin. Modulation by anesthesia, epinephrine, sodium depletion, and renin inhibition. Hypertension 1995;25(5):10214. [PubMed: 7737709]

33. Ingelfinger JR, Zuo WM, Fon EA, Ellison KE, Dzau VJ. In situ hybridization evidence for angiotensinogen messenger RNA in the rat proximal tubule. An hypothesis for the intrarenal renin angiotensin system. J Clin Invest 1990;85:417-23. [PubMed: 2298917] 
34. Nguyen G. The (pro)renin receptor: pathophysiological roles in cardiovascular and renal pathology. Curr Opin Nephrol Hypertens 2007;16:129-33. [PubMed: 17293688]

35. Crowley SD, Gurley SB, Herrera MJ. Angiotensin II causes hypertension and cardiac hypertrophy through its receptors in the kidney. Proc Natl Acad Sci U S A 2006;103:17985-90. [PubMed: 17090678]

36. Ding Y, Davisson RL, Hardy DO, et al. The kidney androgen-regulated protein promoter confers renal proximal tubule cell-specific and highly androgen-responsive expression on the human angiotensinogen gene in transgenic mice. J Biol Chem 1997;272:28142-8. [PubMed: 9346970]

37. Guan S, Fox J, Mitchell KD, Navar LG. Angiotensin and angiotensin converting enzyme tissue levels in two-kidney, one clip hypertensive rats. Hypertension 1992;20:763-7. [PubMed: 1333445]

38. Guyton AC. Dominant role of the kidneys and accessory role of whole-body autoregulation in the pathogenesis of hypertension. Am J Hypertens 1989;2(7):575-85. [PubMed: 2667575]

39. Guyton AC, Coleman TG, Cowley AV Jr, Scheel KW, Manning RD Jr, Norman RA Jr. Arterial pressure regulation. Overriding dominance of the kidneys in long-term regulation and in hypertension. Am J Med 1972 May;52(5):584-94. [PubMed: 4337474]

40. Hall JE, Coleman TG, Guyton AC, Kastner PR, Granger JP. Control of glomerular filtration rate by circulating angiotensin II. Am J Physiol 1981 Sep;241(3):R190-7. [PubMed: 7025662]

41. Kastner PR, Hall JE, Guyton AC. Control of glomerular filtration rate: role of intrarenally formed angiotensin II. Am J Physiol 1984 Jun;246(6 Pt 2):F897-90. [PubMed: 6377913]

42. Gomez RA, Lynch KR, Chevalier RL, et al. Renin and angiotensinogen gene expression and intrarenal renin distribution during ACE inhibition. Am J Physiol 1988;254:F900-6. [PubMed: 2837909]

43. Nguyen G, Delarue F, Burcklé C, Bouzhir L, Giller T, Sraer JD. Pivotal role of the renin/prorenin receptor in angiotensin II production and cellular responses to renin. J Clin Invest 2002;109:141727. [PubMed: 12045255]

44. Saris JJ, 't Hoen PA, Garrelds IM, et al. Prorenin induces intracellular signaling in cardiomyocytes independently of angiotensin II. Hypertension 2006;48:564-71. [PubMed: 16940215]

45. Nabi AH, Kageshima A, Uddin MN, Nakagawa T, Park EY, Suzuki F. Binding properties of rat prorenin and renin to the recombinant rat renin/prorenin receptor prepared by a baculovirus expression system. Int J Mol Med 2006;18:483-8. [PubMed: 16865234]

46. Prescott G, Silversides DW, Reudelhuber TL. Tissue activity of circulating prorenin. Am J Hypertens 2002;15:280-5. [PubMed: 11939621]

47. Kobori H, Ozawa Y, Satou R. Kidney-specific enhancement of ANG II stimulates endogenous intrarenal angiotensinogen in gene-targeted mice. Am J Physiol Renal Physiol 2007;293:F938-45. [PubMed: 17634399]

48. Ichihara A, Hayashi M, Kaneshiro Y. Inhibition of diabetic nephropathy by a decoy peptide corresponding to the "handle" region for nonproteolytic activation of prorenin. J Clin Invest 2004;114:1128-35. [PubMed: 15489960]

49. Ichihara A, Kobori H, Nishiyama A, Navar LG. Renal renin-angiotensin system. Contrib Nephrol 2004;143:117-30. [PubMed: 15248360]

50. Harrison-Bernard LM, Zhuo J, Kobori H, Ohishi M, Navar LG. Intrarenal AT(1) receptor and ACE binding in ANG II-induced hypertensive rats. Am J Physiol Renal Physiol 2002;282:F19-25. [PubMed: 11739108]

51. Kobori H, Prieto-Carrasquero MC, Ozawa Y, Navar LG. AT1 receptor mediated augmentation of intrarenal angiotensinogen in angiotensin II-dependent hypertension. Hypertension 2004;43:112632. [PubMed: 15037565]

52. Darby IA, Sernia C. In situ hybridization and immunohistochemistry of renal angiotensinogen in neonatal and adult rat kidneys. Cell Tissue Res 1995;281:197-206. [PubMed: 7648615]

53. Imig JD, Navar GL, Zou LX, et al. Renal endosomes contain angiotensin peptides, converting enzyme, and AT(1A) receptors. Am J Physiol 1999;277:F303-11. [PubMed: 10444586]

54. Casarini DE, Boim MA, Stella RC, Krieger-Azzolini MH, Krieger JE, Schor N. Angiotensin Iconverting enzyme activity in tubular fluid along the rat nephron. Am J Physiol 1997;272:F405-9. [PubMed: 9087685]

55. Danser AH, Admiraal PJ, Derkx FH, Schalekamp MA. Angiotensin I-to-II conversion in the human renal vascular bed. J Hypertens 1998;16:2051-2056. [PubMed: 9886896] 
56. Navar LG, Nishiyama A. Intrarenal formation of angiotensin II. Contrib Nephrol 2001;135:1-15. [PubMed: 11705276]

57. Siragy HM, Carey RM. Protective role of the angiotensin AT2 receptor in a renal wrap hypertension model. Hypertension 1999;33:1237-42. [PubMed: 10334818]

58. Nishiyama A, Seth DM, Navar LG, et al. Renal interstitial fluid concentrations of angiotensins I and II in anesthetized rats. Hypertension 2002;39:129-34. [PubMed: 11799091]

59. Komlosi P, Fuson AL, Fintha A, et al. Angiotensin I conversion to angiotensin II stimulates cortical collecting duct sodium transport. Hypertension 2003;42:195-9. [PubMed: 12835330]

60. Zou LX, Imig JD, Hymel A, Navar LG. Renal uptake of circulating angiotensin II in Val5-angiotensin II infused rats is mediated by AT1 receptor. Am J Hypertens 1998;11:570-8. [PubMed: 9633793]

61. Ingert C, Grima M, Coquard C, Barthelmebs M, Imbs JL. Contribution of angiotensin II internalization to intrarenal angiotensin II levels in rats. Am J Physiol Renal Physiol 2002;283:F1003-10. [PubMed: 12372776]

62. Li XC, Carretero OA, Navar LG, Zhuo JL. AT1 receptor-mediated accumulation of extracellular angiotensin II in proximal tubule cells: role of cytoskeleton microtubules and tyrosine phosphatases. Am J Physiol Renal Physiol 2006;291:F375-83. [PubMed: 16478976]

63. Zhuo JL, Carretero OA, Li XC, et al. Effects of AT1 receptor-mediated endocytosis of extracellular Ang II on activation of nuclear factor-kappa B in proximal tubule cells. Ann N Y Acad Sci 2006;1091:336-45. [PubMed: 17341626]

64. Haller H, Lindschau C, Erdmann B, Quass P, Luft FC. Effects of intracellular angiotensin II in vascular smooth muscle cells. Circ Res 1996;79:765-72. [PubMed: 8831500]

65. Navar LG, Harrison-Bernard LM, Nishiyama A, Kobori H. Regulation of intrarenal angiotensin II in hypertension. Hypertension 2002;39:316-22. [PubMed: 11882566]

66. Chen R, Mukhin YV, Garnovskaya MN, et al. A functional angiotensin II receptor-GFP fusion protein: evidence for agonist-dependent nuclear translocation. Am J Physiol Renal Physiol 2000;279:F4408. [PubMed: 10966923]

67. Shibata S, Nagase M, Yoshida S, Kawachi H, Fujita T. Podocyte as the target for aldosterone: roles of oxidative stress and Sgk1. Hypertension 2007;49:355-64. [PubMed: 17200434]

68. Duc C, Farman N, Canessa CM, Bonvalet JP, Rossier BC. Cell-specific expression of epithelial sodium channel alpha, beta, and gamma subunits in aldosterone-responsive epithelia from the rat: localization by in situ hybridization and immunocytochemistry. J Cell Biol 1994;127:1907-21. [PubMed: 7806569]

69. Sechi LA, Griffin CA, Giacchetti G, et al. Tissue-specific regulation of type 1 angiotensin II receptor mRNA levels in the rat. Hypertension 1996;28:403-8. [PubMed: 8794824]

70. Tufro-McReddie A, Harrison JK, Everett AD, Gomez RA. Ontogeny of type 1 angiotensin II receptor gene expression in the rat. J Clin Invest 1993;91:530-7. [PubMed: 8432862]

71. Matsubara H, Sugaya T, Murasawa S, et al. Tissue-specific expression of human angiotensin II AT1 and AT2 receptors and cellular localization of subtype mRNAs in adult human renal cortex using in situ hybridization. Nephron 1998;80:25-34. [PubMed: 9730699]

72. Sechi LA, Grady EF, Griffin CA, Kalinyak JE, Schambelan M. Distribution of angiotensin II receptor subtypes in rat and human kidney. Am J Physiol 1992;262:F236-40. [PubMed: 1539685]

73. Harrison-Bernard LM, Navar LG, Ho MM, Vinson GP, el-Dahr SS. Immunohistochemical localization of ANG II AT1 receptor in adult rat kidney using a monoclonal antibody. Am J Physiol 1997;273:F170-7. [PubMed: 9249605]

74. Sachse A, Wolf G. Angiotensin II-induced reactive oxygen species and the kidney. J Am Soc Nephrol 2007;18:2439-46. [PubMed: 17687073]

75. Asaba K, Tojo A, Onozato ML. Effects of NADPH oxidase inhibitor in diabetic nephropathy. Kidney Int 2005;67:1890-8. [PubMed: 15840036]

76. Geiszt M, Kopp JB, Várnai P, Leto TL. Identification of renox, an NAD(P)H oxidase in kidney. Proc Natl Acad Sci U S A 2000;97:8010-4. [PubMed: 10869423]

77. Jones SA, Hancock JT, Jones OT, Neubauer A, Topley N. The expression of NADPH oxidase components in human glomerular mesangial cells: detection of protein and mRNA for p47phox, p67phox, and p22phox. J Am Soc Nephrol 1995;5:1483-91. [PubMed: 7703387] 
78. Miyata K, Rahman M, Shokoji T. Aldosterone stimulates reactive oxygen species production through activation of NADPH oxidase in rat mesangial cells. J Am Soc Nephrol 2005;16:2906-12. [PubMed: 16135774]

79. Orient A, Donkó A, Szabó A, Leto TL, Geiszt M. Novel sources of reactive oxygen species in the human body. Nephrol Dial Transplant 2007;22:1281-8. [PubMed: 17347280]

80. Radeke HH, Cross AR, Hancock JT. Functional expression of NADPH oxidase components (alphaand beta-subunits of cytochrome b558 and 45-kDa flavoprotein) by intrinsic human glomerular mesangial cells. J Biol Chem 1991;266:21025-9. [PubMed: 1657945]

81. Shiose A, Kuroda J, Tsuruya K. A novel superoxide-producing NAD(P)H oxidase in kidney. Biol Chem 2001;276:1417-23.

82. Lambeth JD. Nox enzymes, ROS, and chronic disease: an example of antagonistic pleiotropy. Free Radic Biol Med 2007;43:332-47. [PubMed: 17602948]

83. Schlüter T, Grimm R, Steinbach A, Lorenz G, Rettig R, Grisk O. Neonatal sympathectomy reduces NADPH oxidase activity and vascular resistance in spontaneously hypertensive rat kidneys. Am J Physiol Regul Integr Comp Physiol 2006;291:R391-9. [PubMed: 16914424]

84. Gorin Y, Ricono JM, Kim NH, Bhandari B, Choudhury GG, Abboud HE. Nox4 mediates angiotensin II-induced activation of Akt/protein kinase B in mesangial cells. Am J Physiol Renal Physiol 2003;285:F219-29. [PubMed: 12842860]

85. Moriwaki K, Kiyomoto H, Hitomi H. Interferon-gamma enhances superoxide production in human mesangial cells via the JAK-STAT pathway. Kidney Int 2006;70:788-93. [PubMed: 16820786]

86. Bek MJ, Reinhardt HC, Fischer KG. Up-regulation of early growth response gene-1 via the CXCR3 receptor induces reactive oxygen species and inhibits $\mathrm{Na}+\mathrm{K}+$-ATPase activity in an immortalized human proximal tubule cell line. J Immunol 2003;170:931-40. [PubMed: 12517959]

87. Fujii S, Zhang L, Kosaka H. Albuminuria, expression of nicotinamide adenine dinucleotide phosphate oxidase and monocyte chemoattractant protein-1 in the renal tubules of hypertensive Dahl saltsensitive rats. Hypertens Res 2007;30:991-8. [PubMed: 18049032]

88. Kagawa T, Takao T, Horino T. Angiotensin II receptor blocker inhibits tumour necrosis factor-alphainduced cell damage in human renal proximal tubular epithelial cells. Nephrology (Carlton) 2008;13:309-15. [PubMed: 18331441]

89. Vetter M, Chen ZJ, Chang GD, Che D, Liu S, Chang CH. Cyclosporin A disrupts bradykinin signaling through superoxide. Hypertension 2003;41:1136-42. [PubMed: 12695417]

90. Wolf G, Hannken T, Schroeder R, Zahner G, Ziyadeh FN, Stahl RA. Antioxidant treatment induces transcription and expression of transforming growth factor beta in cultured renal proximal tubular cells. FEBS Lett 2001;488:154-9. [PubMed: 11163763]

91. Lassègue $\mathrm{B}$, Clempus RE. Vascular NAD(P)H oxidases: specific features, expression, and regulation. Am J Physiol Regul Integr Comp Physiol 2003;285:R277-97. [PubMed: 12855411]

92. Zou AP, Li N, Cowley AW Jr. Production and actions of superoxide in the renal medulla. Hypertension 2001;37:547-53. [PubMed: 11230333]

93. Etoh T, Inoguchi T, Kakimoto M. Increased expression of NAD(P)H oxidase subunits, NOX4 and p22phox, in the kidney of streptozotocin-induced diabetic rats and its reversibity by interventive insulin treatment. Diabetologia 2003;46:1428-37. [PubMed: 13680125]

94. Gojo A, Utsunomiya K, Taniguchi K. The Rho-kinase inhibitor, fasudil, attenuates diabetic nephropathy in streptozotocin-induced diabetic rats. Eur J Pharmacol 2007;568:242-7. [PubMed: 17511984]

95. Benter IF, Yousif MH, Dhaunsi GS, Kaur J, Chappell MC, Diz DI. Angiotensin-(1-7) prevents activation of NADPH oxidase and renal vascular dysfunction in diabetic hypertensive rats. Am J Nephrol 2008;28(1):25-33. [PubMed: 17890855]

96. Gorin Y, Block K, Hernandez J. Nox4 NAD(P)H oxidase mediates hypertrophy and fibronectin expression in the diabetic kidney. J Biol Chem 2005;280:39616-26. [PubMed: 16135519]

97. Whaley-Connell A, Habibi J, Nistala R. Attenuation of NADPH oxidase activation and glomerular filtration barrier remodeling with statin treatment. Hypertension 2008;51:474-80. [PubMed: 18172055] 
98. van Ittersum FJ, de Man AM, Thijssen S. Genetic polymorphisms of the renin-angiotensin system and complications of insulin-dependent diabetes mellitus. Nephrol Dial Transplant 2000;15:1000 7. [PubMed: 10862638]

99. Kobori H, Katsurada A, Miyata K, et al. Determination of plasma and urinary angiotensinogen levels in rodents by newly developed ELISA. Am J Physiol Renal Physiol 2008;294:F1257-63. [PubMed: 18353869]

100. Campese VM, Park J. HMG-CoA reductase inhibitors and renal function. Clin J Am Soc Nephrol 2007;2:1100-3. [PubMed: 17942762]

101. Feldman DL, Jin L, Xuan H. Effects of aliskiren on blood pressure, albuminuria, and (pro)renin receptor expression in diabetic TG(mRen-2)27 rats. Hypertension 2008;52:130-6. [PubMed: 18490518]

102. Parving HH, Persson F, Lewis JB, Lewis EJ, Hollenberg NK. AVOID Study Investigators. Aliskiren combined with losartan in type 2 diabetes and nephropathy. N Engl J Med 2008;358:2433-46. [PubMed: 18525041]

103. Bakris GL. Pharmacological augmentation of endothelium-derived nitric oxide synthesis. J Manag Care Pharm 2007;13:S9-12. [PubMed: 17605505] 


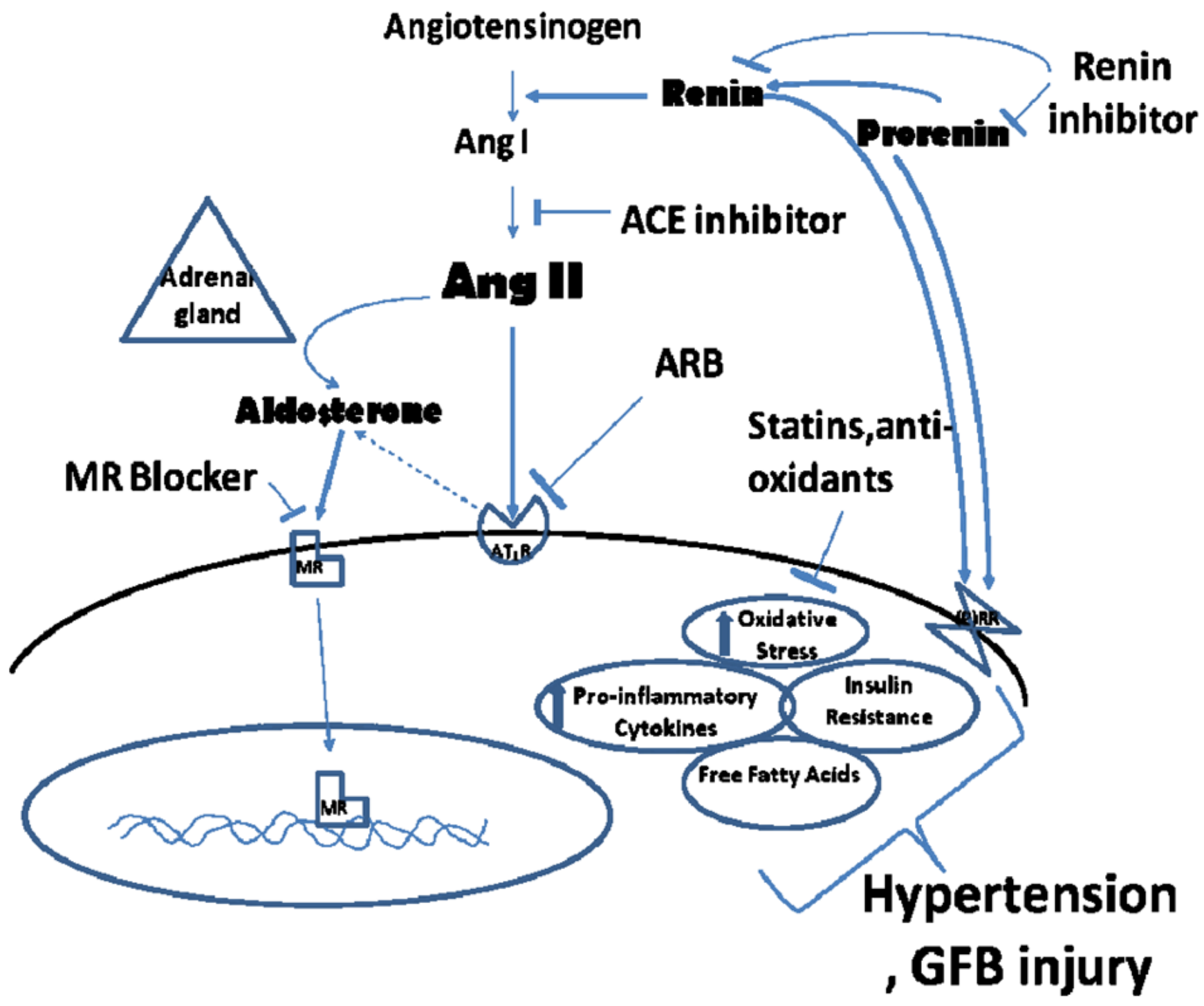

Figure 1.

This figure illustrates the renin-angiotensin-aldosterone system (RAAS) in and around a cell in the kidney. Post receptor signaling is a complicated process and has been minimized to emphasize the link between RAAS and oxidative stress, inflammation, insulin resistance and sclerosis. Ultimately, the result of an overactive kidney RAAS is associated with hypertension and GFB injury. Sites of action for RAAS blocking drugs are depicted. ACE $=$ angiotensin converting enzyme, $\mathrm{ARB}=$ angiotensin receptor blocker, $\mathrm{MR}=$ mineralocorticoid receptor, $\mathrm{GFB}=$ glomerular filtration barrier 


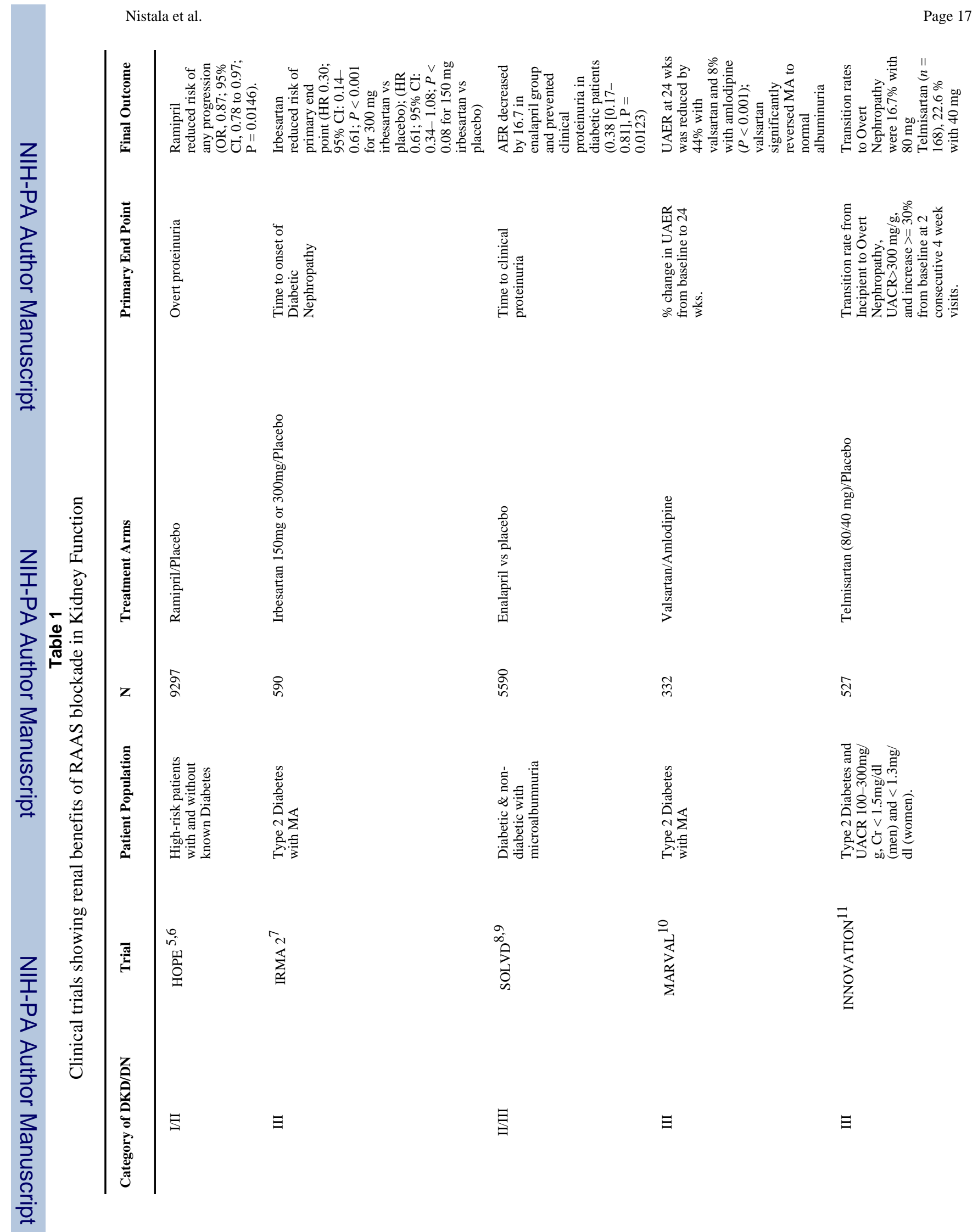

Transl Res. Author manuscript; available in PMC 2010 March 1. 


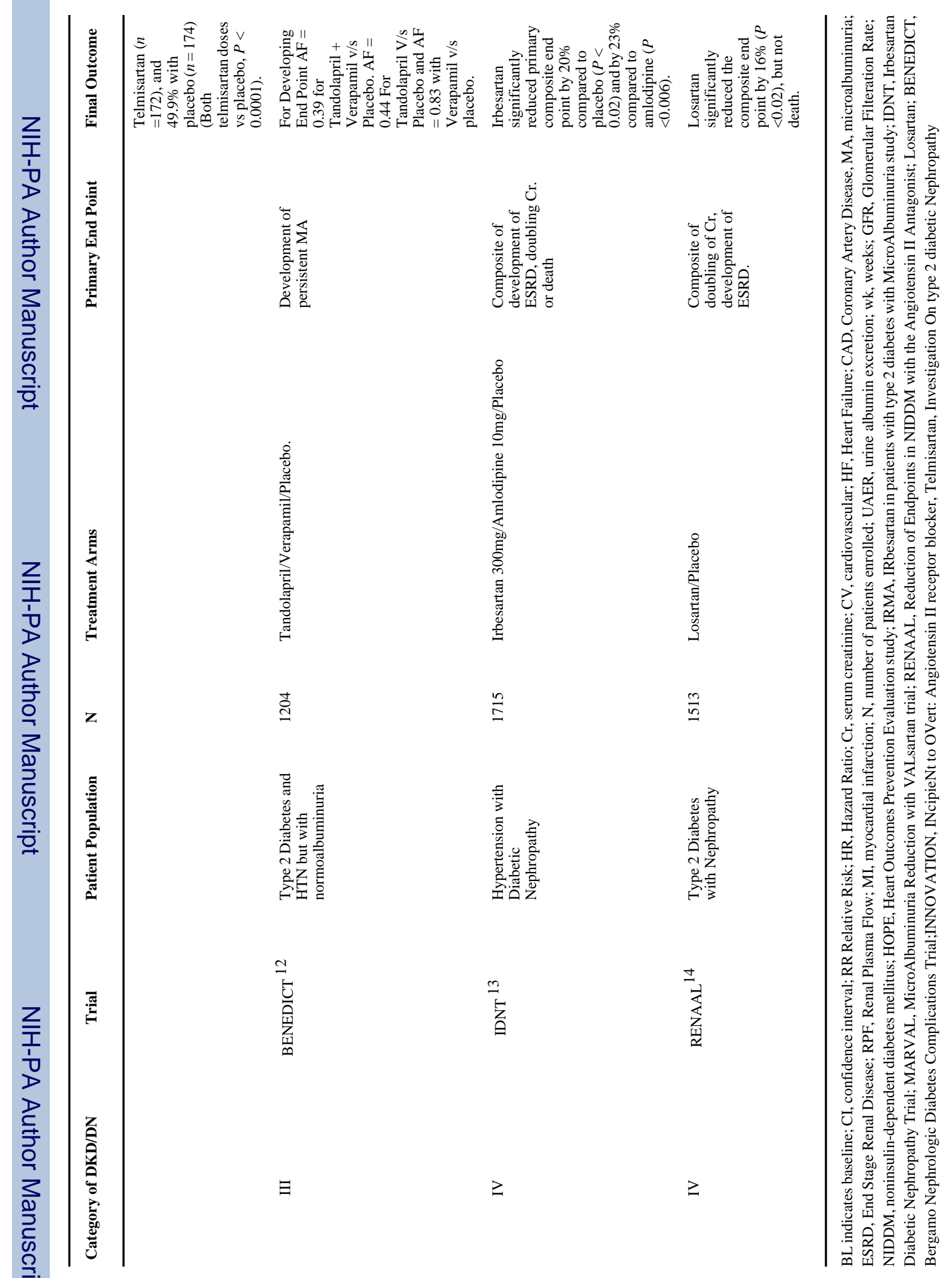

Transl Res. Author manuscript; available in PMC 2010 March 1. 